\title{
Circulating Immune Complexes in Lyme Arthritis
}

\author{
DETECTION BY THE ${ }^{125}$ I-Clq BINDING, Clq SOLID PHASE,
} AND RAJI CELL ASSAYS

\author{
John A. Hardin, Lesley C. Walker, Allen C. Steere, Thomas C. Trumble, \\ Kenneth S. K. Tung, Ralph C. Williams, Jr., Shaun Ruddy, and \\ Stephen E. Malawista, Department of Medicine, Yale University School of \\ Medicine, New Haven, Connecticut 06510; Department of Medicine, Medical \\ College of Virginia, Richmond, Virginia 23298; and Departments of Pathology \\ and Medicine, University of New Mexico School of Medicine, Albuquerque, \\ New Mexico 87131
}

\begin{abstract}
A в S T R A C T We have found immunoglobulin(Ig)Gcontaining material consistent with immune complexes in the sera of patients with Lyme arthritis. It was detected in 29 of 55 sera $(55 \%)$ from 31 patients by at least one of three assays: ${ }^{125} \mathrm{I}-\mathrm{Clq}$ binding, $\mathrm{Clq}$ solid phase, or Raji cell. The presence of reactive material correlated with clinical aspects of disease activity; it was found early in the illness, was most prominent in sera from the sickest patients, was infrequent during remissions, and often fluctuated in parallel with changes in clinical status. The results in the two $\mathrm{Clq}$ assays showed a strong positive correlation $(P<0.001)$. They were each elevated in $45 \%$ of the sera and were usually concordant (85\%). In contrast, the Raji cell assay was less frequently positive and often discordant with the Clq assays. In sucrose density gradients, putative circulating immune complexes sedimented near 19S; they, too, were detected best by the two assays based on Clq binding. An additional 7S component was found in some sera by the ${ }^{125} \mathrm{I}-\mathrm{Clq}$ binding assay. Serum complement was often above the range of normal in patients with mild disease and normal in patients with severe disease but did not correlate significantly with levels of circulating immune complexes. IgM and IgG rheumatoid factors were not detectable.

These findings support a role for immune complexes in the pathogenesis of Lyme arthritis. Their measurement, by either the ${ }^{125} \mathrm{I}-\mathrm{Clq}$ binding assay or by the $\mathrm{Clq}$ solid phase assay, often provides a sensitive index
\end{abstract}

Doctors Hardin and Steere are postdoctoral fellows of the Arthritis Foundation.

Received for publication 14 July 1978 and in revised form 27 October 1978. of disease activity. Moreover, the complexes are likely sources of disease-related antigens for further study of this new disorder.

\section{INTRODUCTION}

Lyme arthritis is a newly recognized epidemic disease that has been occurring at least since 1972 in southeastern Connecticut and other areas bordering Long Island Sound. It is characterized by recurrent attacks of asymmetric large joint arthritis, by geographic and seasonal clustering, and by the presence of a unique preceding skin lesion, erythema chronicum migrans $(E C M)^{1}(1)$. Although many patients have had only ECM with or without mild synovitis, others have developed sustained inflammatory joint disease, and some have also had meningoencephalitis, peripheral neuropathy, or cardiac conduction abnormalities (2). Thus far, efforts to identify a causative agent have been unsuccessful, but epidemiologic studies have indicated transmission by a tick vector (1-4). Rheumatoid factor has been absent in virtually all patients. Synovial biopsy specimens have revealed changes resembling those found in rheumatoid arthritis, including synovial hypertrophy, vascular proliferation, and heavy infiltration with lymphocytes and plasma cells (2).

We have previously reported that serum cryoimmunoglobulins occur in some patients with Lyme arthritis, particularly in those with active arthritis or in those with ECM who later develop arthritis (5).

\footnotetext{
${ }^{1}$ Abbreviations used in this paper: $\mathrm{CH} 50$, total hemolytic complement; ECM, erythema chronicum migrans; MEM, Dulbecco's modified minimum essential medium; PBS, phosphate-buffered saline.
} 
These observations suggested that immune complexes might play a role in the pathophysiology of this illness. We postulated that such complexes, if present, might contain antigen(s) related to the elusive causative agent. Furthermore, the seasonal onset and cyclical nature of the illness and the presence of a pre-articular phase (especially ECM) would make it a convenient human model for studying how early immune responses are related to the development of inflammatory joint disease and other clinical events. Consequently, we have looked for evidence of circulating immune complexes in the serum of patients with Lyme arthritis by three standard assay systems: the ${ }^{125} \mathrm{I}-\mathrm{Clq}$ binding assay, which detects immune complexes composed of complement-fixing immunoglobulins of any class (6); the $\mathrm{Clq}$ solid phase assay, which detects immune complexes composed of complement fixing, staphylococcal protein A-reactive $\operatorname{IgG}(7,8)$; and the Raji cell assay, which detects immune complexes that bind to cell surface receptors, principally those for C3b and C3d (9).

\section{METHODS}

Patients. To compare the results in the three assays for immune complexes, we studied 31 patients with Lyme arthritis who were between the ages of 3 and $67 \mathrm{yr}$. The clinical features of these patients were described previously $(1,2)$. In general, the initial feature of the illness was ECM, which typically lasted for about 3 wk. Approximately 2 wk to 5 mo after the onset of the skin lesion, most patients developed recurrent attacks of arthritis, usually of large joints. Extra-articular complications occurred in three patients. The diagnosis of Lyme arthritis was based on patients having the unique preceding skin lesion of ECM, typical attacks of oligoarthritis, and residency in the endemic area. At each clinic visit, blood to be tested for immune complexes was collected, and on the basis of their history and physical findings, patients were assigned to one of the following categories of disease activity: (a) skin: patients with only ECM; $(b)$ joints: patients with arthritis; ECM still present or not, but no other systems involved; $(c)$ heart: patients with cardiac conduction abnormalities, regardless of ECM, arthritis, or peripheral neuropathy; $(d)$ central nervous system: patients with meningitis or meningoencephalitis (documented by abnormal cerebrospinal fluid), regardless of all other features; $(e)$ peripheral nervous system: patients with a peripheral neuropathy, without central nervous system or heart involvement, and regardless of skin or joint involvement; ( $f$ ) remission: patients with no symptoms or signs for at least $2 \mathrm{wk}$. To define the relationship of immune complexes to the clinical course of Lyme arthritis, we followed these and an additional 27 patients during various phases of their illness with the ${ }^{125} \mathrm{I}-\mathrm{Clq}$ binding assay. For this purpose, when multiple serum samples were taken from individual patients, the results of the first sample obtained during a given phase of the illness was tabulated.

Blood for immume complex assays was drawn in Vacutainer tubes (Becton, Dickinson \& Co., Rutherford, N. J.) and allowed to clot for $1 \mathrm{~h}$ at $25^{\circ} \mathrm{C}$. After centrifugation the serum was collected, stored in aliquots at $-70^{\circ} \mathrm{C}$ in polypropylene vials (Electro-Sonic Co., Hawthorne, Calif.), and thawed a single time for assay. At the time the assays were performed, the oldest serum had been stored for $10 \mathrm{mo}$.
Preparation of Clq. Clq was isolated from human serum by the method of Yonemasu and Stroud (10), dissolved in barbital-buffered saline $\left(0.02 \mathrm{M} \mathrm{Na}\right.$ barbital, $2.5 \mathrm{mM} \mathrm{Ca} \mathrm{Cl}_{2}$, $0.75 \mathrm{mM} \mathrm{MgCl}_{2}, \mathrm{pH} \mathrm{7.3)}$, and stored at $-70^{\circ} \mathrm{C}$ until used. The isolated $\mathrm{Clq}$ readily agglutinated latex particles coated with aggregated IgG and did not react with antisera to IgG, IgA, or IgM in double immunodiffusion in $1 \%$ agarose gels.

The ${ }^{125} \mathrm{I}-\mathrm{Cl} \mathrm{q}$ binding assay. $200 \mu \mathrm{g}$ of isolated Clq was radiolabelled with ${ }^{125} \mathrm{I}$ (New England Nuclear, Boston, Mass.) by a modification of the lactoperoxidase technique (11) to a specific activity of 0.6 to $0.9 \mathrm{mCi} / \mu \mathrm{g}$ of protein, and $10-\mu \mathrm{g}$ aliquots were stored in $100 \mu \mathrm{l}$ of barbital-buffered saline at $-70^{\circ} \mathrm{C}$. Before use, each aliquot was thawed, diluted to $5 \mathrm{ml}$ with barbital-buffered saline containing $1 \%$ bovine serum albumin (A grade, Calbiochem, San Diego, Calif.) and centrifuged at $20,000 \mathrm{~g}$ for $40 \mathrm{~min}$ at $4^{\circ} \mathrm{C}$ to remove aggregated protein.

The assay was performed in triplicate as described by Zubler et al. (6). $50 \mu \mathrm{l}$ of unheated test serum was combined in Bio Vial polypropylene tubes (Beckman Instruments, Inc., Fullerton, Calif.) with $100 \mu$ l of $0.2 \mathrm{M} \mathrm{Na}_{2}$ EDTA (pH 7.5 , adjusted with $\mathrm{NaOH}$ ) and incubated for $30 \mathrm{~min}$ at $37^{\circ} \mathrm{C}$. Then, in an ice bath, $50 \mu \mathrm{l}$ of the ${ }^{125} \mathrm{I}-\mathrm{Clq}$ and $1 \mathrm{ml}$ of $3 \%$ polyethylene glycol, 6,000 mol wt (Fisher Scientific Co., Pittsburgh, Pa.) in borate buffer $(0.1 \mathrm{M}$ boric acid, $0.25 \mathrm{M}$ disodium-tetraborate, $0.075 \mathrm{M} \mathrm{NaCl}, \mathrm{pH} 8.3$ ) were added. The mixture was then maintained at $4^{\circ} \mathrm{C}$ for $60 \mathrm{~min}$ to facilitate insolubilization of the ${ }^{125} \mathrm{I}-\mathrm{Clq}$ bound by immune complexes. The resulting precipitate was collected by centrifugation at $1,500 \mathrm{~g}$ for $20 \mathrm{~min}$, and the supernate carefully removed by aspiration. Radioactivity in the precipitate was measured in an automated gamma spectrometer (Biogamma 4000, Beckman Instruments, Inc.). Precision and reproducibility studies of this method, done with a positive control serum from a patient with rheumatoid vasculitis and cryoglobulinemia, revealed a coefficient of variation of $4 \%$ among 10 aliquots tested on the same day, and $11 \%$ among 7 aliquots tested on separate days.

The Clq solid phase assay. The assay was performed in duplicate by a modification (12) of the method described by Hay et al. (8). To coat the test tubes, isolated Clq was diluted to a concentration of $10 \mu \mathrm{g} / \mathrm{ml}$ in phosphate-buffered saline (PBS, $0.01 \mathrm{M}$ phosphate, $0.15 \mathrm{M} \mathrm{NaCl}, \mathrm{pH} 7.4$ ) with $0.02 \%$ azide, and 1-ml aliquots were incubated in Falcon $12 \times 75-\mathrm{mm}$ polystyrene tubes (Falcon Plastics, Div. BioQuest, Oxnard, Calif.) overnight at $4^{\circ} \mathrm{C}$. The tubes were then washed three times in ice-cold PBS, filled with $1.5 \mathrm{ml}$ of $0.3 \%$ gelatin in PBS/azide, incubated at room temperature for $2 \mathrm{~h}$, and finally washed again three times with ice-cold PBS-azide containing $0.05 \%$ tween 20 (Matheson, Coleman \& Bell, East Rutherford, N. J.) (PBS/tween). For the assay, $50 \mu \mathrm{l}$ of test serum and $100 \mu \mathrm{l}$ of Na EDTA were incubated together for $30 \mathrm{~min}$ as in the ${ }^{125} \mathrm{I}-\mathrm{Clq}$ assay. Then $50-\mu \mathrm{l}$ samples were placed in the Clq-coated tubes together with $950 \mu \mathrm{l}$ of PBS/ tween and the mixture incubated at $37^{\circ} \mathrm{C}$ for $60 \mathrm{~min}$ and at $4^{\circ} \mathrm{C}$ for $30 \mathrm{~min}$. Unbound proteins were then removed by three washes with cold PBS/tween. IgG-containing immune complexes that remained bound to the $\mathrm{Clq}$-coated tubes were presented with $1 \mathrm{ml}$ of $\mathrm{PBS} /$ tween containing $\cong 25 \mathrm{ng}$ of staphylococcal protein A (Pharmacia Fine Chemicals, Piscataway, N. J.) previously radiolabeled with ${ }^{125}$ I by the chloramine-T method (13). The tubes were then incubated at $37^{\circ} \mathrm{C}$ for $60 \mathrm{~min}$ and at $4^{\circ} \mathrm{C}$ for $30 \mathrm{~min}$, and finally washed three times with cold PBS/tween. The radioactivity that remained bound to the tubes was then measured. The coefficient of variation was $1.9 \%$ among duplicates of 50 samples tested on the same day, and $5.8 \%$ among positive controls tested on 10 separate days.

The Raji cell assay. The assay was performed in triplicate as described by Theofilopoulos et al (9). Raji cells (a gift of 
Doctors Theofilopoulos and Dixon, Scripps Clinic and Research Foundation, La Jolla, Calif.) were grown in Dulbecco's modified minimum essential media (MEM) with 5\% fetal calf serum (Grand Island Biological Co., Grand Island, $\mathrm{N}$. Y.). $2 \times 10^{6}$ cells in $20 \mu \mathrm{l}$ of MEM were placed in $1.5-\mathrm{ml}$ microfuge tubes (Beckman Instruments, Inc.) along with $25 \mu \mathrm{l}$ of test serum diluted 1:4 with MEM, and incubated at $37^{\circ} \mathrm{C}$ for 45 min with gentle agitation at 10 -min intervals. Subsequently, the cells were washed three times with MEM, resuspended in $50 \mu \mathrm{l}$ of ${ }^{125} \mathrm{I}$-rabbit anti-human IgG (labelled by the chloramine-T method) that had been diluted 1:2 with MEM containing $1 \%$ rabbit serum albumin (Sigma Chemical Co., St. Louis, Mo.), and then incubated at $4^{\circ} \mathrm{C}$ for $30 \mathrm{~min}$ with gentle agitation at 5-min intervals. Finally, the cells were washed three more times with cold MEM containing $1 \%$ rabbit serum albumin and the cell-bound radioactivity was measured. The coefficient of variation was $9.8 \%$ among triplicates of 30 samples tested on the same day, and 10.5\% among positive controls tested on 10 separate days.

Density gradient ultracentrifugation. The relative molecular size and distribution of material reactive in the assays for immune complexes were studied by density gradient ultracentrifugation under two experimental conditions. For the ${ }^{125} \mathrm{I}-\mathrm{Clq}$ binding assay, test sera $(300 \mu \mathrm{l})$ diluted 1:2 with PBS were layered over $4.5 \mathrm{ml}$, linear, $10-40 \%$ sucrose gradients in PBS, and centrifuged at $192,000 \mathrm{~g}$ for $14 \mathrm{~h}$ in a SW 50.1 rotor (Beckman Instruments, Inc.). In a separate tube, ${ }^{125} \mathrm{I}-\mathrm{IgG}(7 \mathrm{~S})$ and IgM (19S) were used as reference markers. The tubes were punctured and gradient fractions $(0.25 \mathrm{ml})$ were collected from the bottom. The individual fractions were analyzed for immune complexes in the same manner as serum.

For the Clq solid phase and Raji cell assays, $0.25 \mathrm{ml}$ of $1: 2$ dilutions of test sera were applied to $4.5 \mathrm{ml}$, linear, 10-37\% sucrose gradients in PBS and centrifuged at 222,000 $\mathrm{g}$ for $6.2 \mathrm{~h}$ in a SW 50.1 rotor. Fractions $(0.3 \mathrm{ml})$ were collected from the top of the gradients by a density gradient fractionator (Instrumentation Specialties Co., Lincoln, Nebr.). $100 \mu \mathrm{l}$ from each fraction, in the absence of EDTA, was assayed in duplicate for the presence of immune complexes in the Clq solid phase assay, and at a dilution of 1:2 in MEM in the Raji cell assay. The IgG content of the fractions was quantified by a solid phase radioimmunoassay (12). Sucrose present in the fractions did not interfere with the assays.

Analysis of results. We wished to compare sera from patients with Lyme arthritis directly with sera from normal donors. Consequently, we eliminated the use of standard curves based on the reactivity of aggregated IgG and instead made a direct statistical comparison of the reactivity of normal and test sera. 50 sera from normal donors were surveyed with each assay. Approximately $5 \%$ (in the ${ }^{125} \mathrm{I}-\mathrm{Clq}$ binding assay and the Raji cell assay) to $10 \%$ (in the $\mathrm{Clq}$ solid phase assay) were reactive by $2-6 \mathrm{SD}$ above the mean, and these sera were excluded on the grounds that they contained an excess of reactive material, possibly immune complexes. The reactivity of the remaining sera approximated a Gaussian distribution. At the time of each assay, 10 normal sera representative of the larger panel were included with the test sera. The mean and SD of the radioactivity bound in the assays of the normal sera were calculated and the differences in the reactivity of the test sera from the normals were expressed as multiples of this SD. Test sera with reactivity $>2$ SD above the mean were considered positive.

Detection of rheumatoid factors. Anti-immunoglobulins of the IgG class were measured by the method of Hay et al. (14). Falcon polystyrene tubes $(10 \times 75 \mathrm{~mm})$ were coated with rabbit IgG (Cappel Laboratories, Inc., Downingtown, Pa.), $10 \mathrm{mg} /$ liter in PBS for $1 \mathrm{~h}$ at $37^{\circ} \mathrm{C}$, and then overnight at $4^{\circ} \mathrm{C}$. After three washes with PBS, the tubes were incubated for $2 \mathrm{~h}$ at room temperature with $1.5 \mathrm{ml}$ of $0.3 \%$ gelatin solution in PBS followed by three washes with PBS containing $0.05 \%$ tween 20. Test sera were heated at $56^{\circ} \mathrm{C}$ for $30 \mathrm{~min}$ to inactivate complement, and duplicate $50-\mu$ l samples together with $450 \mu \mathrm{l}$ of PBS/tween 20 were incubated in the coated tubes for $1 \mathrm{~h}$ at $37^{\circ} \mathrm{C}$ and for $30 \mathrm{~min}$ at $4^{\circ} \mathrm{C}$. Subsequently, the tubes were washed three times with PBS/tween 20 and bound antiglobulin was detected by the incubation of the tubes with $1 \mu \mathrm{g}$ of purified (14) heavy-chain specific ${ }^{125} \mathrm{I}-$-rabbit anti-human IgG (Cappel Laboratories, Inc.) at $37^{\circ} \mathrm{C}$ for $1 \mathrm{~h}$ and at $4^{\circ} \mathrm{C}$ for $30 \mathrm{~min}$. The tubes were washed three times with $\mathrm{PBS} /$ tween 20 , and the radioactivity remaining bound was measured. 10 normal sera, representative of the normal range derived from 50 sera, were included in each assay. Sera from patients with rheumatoid-factor positive rheumatoid arthritis and from sero-negative patients with osteoarthritis were used as positive and negative controls.

The standard latex fixation method (Hyland Diagnostics Div., Travenol Laboratories, Inc., Costa Mesa, Calif.) was used to test sera for 19S-IgM rheumatoid factors (15).

Complement and cryoglobulin determinations. Total hemolytic complement ( $\mathrm{CH} 50)$ was measured by the method of Kent and Fife (16) and the third (C3) and fourth (C4) components by radial immunodiffusion in Hyland plates (Hyland Diagnostics Div., Travenol Labs., Inc.). Cryoglobulins were measured as described previously (5).

Statistical evaluation. Patient groups were compared by Fisher's exact test. Correlation coefficients $(r)$ were calculated by a standard program in a Hewlett-Packard HP-97 calculator (Hewlett-Packard Co., Palo Alto, Calif.).

\section{RESULTS}

Assays for immune complexes. In the initial search for circulating immune complexes, we analyzed 55 sera from 31 patients with active Lyme arthritis or a recent remission, simultaneously in the Clq solid phase assay and in the Raji cell assay and subsequently in the ${ }^{125} \mathrm{I}$ Clq binding assay (Table I). Overall, one or more serum samples from $17(55 \%)$ patients reacted in at least one of the assays. Almost all of the positive reactions occurred with sera from patients having active disease (28/46 active disease sera vs. 1/9 inactive disease sera; $P=0.01$ ). Sera from the two sickest patients - those with cardiac and central nervous system involvement-contained reactive material often at higher levels than in other patients. In contrast, reactive material was found in only approximately onehalf of the sera from patients with arthritis (19 of 35) and rarely in patients during remissions ( 1 of 9 ). Two or more sequential samples spanning as many as 9 mo were obtained from 16 patients. Among these samples the results of each assay method tended to remain either consistently positive or negative.

The ${ }^{125} \mathrm{I}-\mathrm{Clq}$ binding assay and the Clq solid phase assay results were usually concordant; they were both positive in 20 sera, both negative in 29 , and were discordant in only 5 instances. Regression analysis demonstrated a strong positive correlation between the numerical values of these two assays $(r=0.65$, $P<0.001)$. In contrast, positive results were less fre- 
TABLE I

Comparison of Clq Binding, Clq Solid Phase, and Raji Cell Assays for Immune Complexes in Patients with Lyme Arthritis

\begin{tabular}{|c|c|c|c|c|c|}
\hline Clinical activity & Pt. & $\begin{array}{c}\text { Intervals between } \\
\text { sequential } \\
\text { samples }\end{array}$ & $\begin{array}{c}{ }^{125} \mathrm{I}-\mathrm{Clq} \\
\text { binding* }\end{array}$ & $\begin{array}{c}\mathrm{Clq} \\
\text { solid } \\
\text { phase }^{*}\end{array}$ & $\begin{array}{l}\text { Raji } \\
\text { cell }^{*}\end{array}$ \\
\hline & & mo & & & \\
\hline \multirow[t]{4}{*}{ Skin } & A & & 4.3 & 2.3 & - \\
\hline & B & & 4.1 & 5.1 & - \\
\hline & C & & - & - & - \\
\hline & $\mathrm{D}$ & & - & - & - \\
\hline \multirow[t]{33}{*}{ Joints } & $\mathrm{E}$ & & 2.1 & 3.7 & - \\
\hline & & 8 & 2.2 & 6.1 & ND \\
\hline & & 9 & 5.0 & 7.8 & - \\
\hline & $\mathrm{F}$ & & 5.0 & 23.0 & 3.4 \\
\hline & & 1 & 4.6 & 16.2 & 4.1 \\
\hline & G & & 2.3 & 3.6 & - \\
\hline & & 1 & 2.6 & 4.3 & - \\
\hline & $\mathbf{H}$ & & 2.4 & - & - \\
\hline & & 0.5 & - & 3.6 & - \\
\hline & I & & 2.1 & 9.9 & - \\
\hline & & 1 & 2.3 & 5.9 & 2.4 \\
\hline & J & & 3.1 & 13.1 & ND \\
\hline & $\mathbf{K}$ & & 2.9 & 2.5 & 9.7 \\
\hline & L & & 8.4 & 22.5 & - \\
\hline & $\mathbf{M}$ & 3 & - & 6.7 & - \\
\hline & $N$ & 2 & ND & - & $\overline{05}$ \\
\hline & o & 2 & - & - & 2.5 \\
\hline & & 1 & - & - & 8.4 \\
\hline & $\mathbf{P}$ & & - & - & ND \\
\hline & & 1 & - & - & - \\
\hline & Q & & - & - & - \\
\hline & $\mathbf{R}$ & & - & - & - \\
\hline & $\mathrm{S}$ & & - & - & - \\
\hline & $\mathrm{T}$ & & - & - & - \\
\hline & C & 3 & - & - & - \\
\hline & $\mathrm{U}$ & & - & - & - \\
\hline & & 8 & - & - & - \\
\hline & & 8.5 & - & - & - \\
\hline & $v$ & & - & - & 2.3 \\
\hline & $\mathbf{W}$ & 0.0 & - & - & 2.0 \\
\hline & $\mathrm{x}$ & & - & - & - \\
\hline & $\mathrm{Y}$ & & - & - & - \\
\hline & & 0.25 & - & - & - \\
\hline \multirow[t]{2}{*}{ Heart } & $\mathbf{M}$ & & 5.0 & 2.7 & - \\
\hline & & 0.25 & 4.7 & 10.5 & - \\
\hline \multirow[t]{4}{*}{ Central nervous system $\S$} & $\mathrm{Z}$ & & 7.4 & 10.9 & 4.3 \\
\hline & & 1 & 14.8 & 9.5 & - \\
\hline & & 4 & 4.9 & 13.6 & - \\
\hline & & 7 & 7.7 & 27.4 & - \\
\hline Peripheral nerv. sys." & $\mathrm{T}$ & 2 & 2.0 & - & 3.4 \\
\hline \multirow[t]{4}{*}{ Remission } & AA & & 4.3 & - & - \\
\hline & & 1 & - & - & - \\
\hline & $\mathrm{C}$ & 1 & - & - & - \\
\hline & & 4 & - & - & - \\
\hline
\end{tabular}


TABLE I (Continued)

\begin{tabular}{|c|c|c|c|c|c|c|}
\hline Clinical activity & Pt. & $\begin{array}{c}\text { Intervals between } \\
\text { sequential } \\
\text { samples }\end{array}$ & & $\begin{array}{l}\text { 1225-Clq } \\
\text { binding* }\end{array}$ & $\begin{array}{c}\text { Clq } \\
\text { solid } \\
\text { phase* }\end{array}$ & $\begin{array}{l}\text { Raji } \\
\text { cell }^{*}\end{array}$ \\
\hline & & mo & & & & \\
\hline & BB & & & - & - & - \\
\hline & $\mathrm{CC}$ & & & - & - & - \\
\hline & $\mathrm{DD}$ & & & - & - & - \\
\hline & $\mathbf{X}$ & 1 & & - & - & - \\
\hline & EE & & & - & - & - \\
\hline \multicolumn{7}{|l|}{ Summary of results } \\
\hline \multirow[t]{2}{*}{ Normal controls } & & & & $2 / 48$ & $8 / 100$ & $3 / 50$ \\
\hline & & & $P$ & $<0.0001$ & $<0.0001$ & NS \\
\hline \multirow{2}{*}{ Patients with active disease } & & & & $13 / 25$ & $12 / 25$ & $5 / 25$ \\
\hline & & & $P$ & NS & 0.02 & NS \\
\hline Patients in remission & & & & $1 / 7$ & $0 / 7$ & $0 / 7$ \\
\hline
\end{tabular}

A dash denotes results within the range of normal.

* SD above mean of normal controls.

† A 30-yr-old man with ECM, arthritis, and intermittent first and second degree atrioventricular node block.

$\S$ An 8-yr-old boy with ECM, arthritis, fever, headache, stiff neck, and cerebrospinal fluid containing predominantly lymphocytes.

"A 32-yr-old woman with fever, headache, arthritis, and Bell's palsy.

quent with the Raji cell assay even though four sera were reactive in this assay alone. These discrepant results were reproducible on repeated testing of the sera. No correlation existed between the results of the Raji cell assay and either of the other two assays.

Complement levels. CH50, C3, and C4 were measured respectively in 25,48 , and 48 of the 55 sera (Fig. 1). In general, complement components behaved as acute phase reactants. Serum levels of CH50 and C3 were often well above the range of normal, particularly in patients with arthritis. Only 5 of the 25 patients with active disease had $\mathrm{CH} 50$ or $\mathrm{C} 4$ levels below the normal range. Complement levels did not correlate with the presence of immune complexes as detected by any of the three assays.

Density gradient studies. Because it seemed likely that disparate results in the three immune complex assays were the result of the presence either of different types of complexes or of some other reactive material, the assays were applied to a group of sera after sucrose density gradient ultracentrifugation. Initially, the ${ }^{125} \mathrm{I}-$ $\mathrm{Clq}$ binding assay was used to compare sera from patients with early mild disease (ECM alone) with those from patients with later, more severe disease (arthritis, meningoencephalitis) (Fig. 2). In both groups, there were two peaks of reactivity, one sedimenting just below the 7S marker and another near the 19S marker. In the patients with only ECM, the two peaks were of approximately equal size, but in the patients with arthritis or meningoencephalitis, the $19 \mathrm{~S}$ peak predominated. Al- though the more dense material was compatible with immune complexes, reactivity in the material sedimenting near the 7S marker was more difficult to account for. Immune complexes composed of single IgG molecules and small antigens might have sedimentation coefficients near 7S. However, they would presumably be too small to fix complement and therefore should not react in the assay (17). Other possibilities that could account

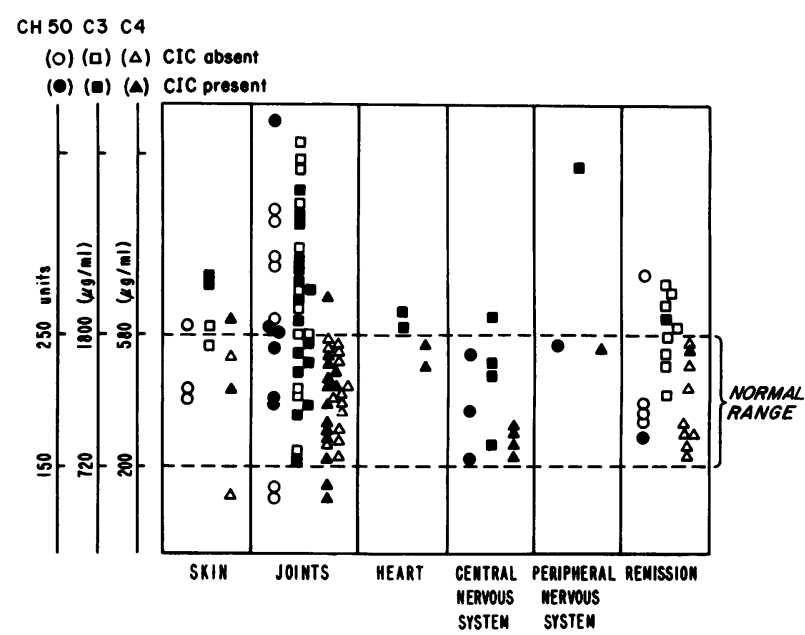

Figure 1 Serum complement levels are seen in Lyme arthritis patients with or without evidence of circulating immune complexes (CIC), as detected by ${ }^{125} \mathrm{I}-\mathrm{Clq}$ binding, Clq solid phase, or Raji cell assays. 


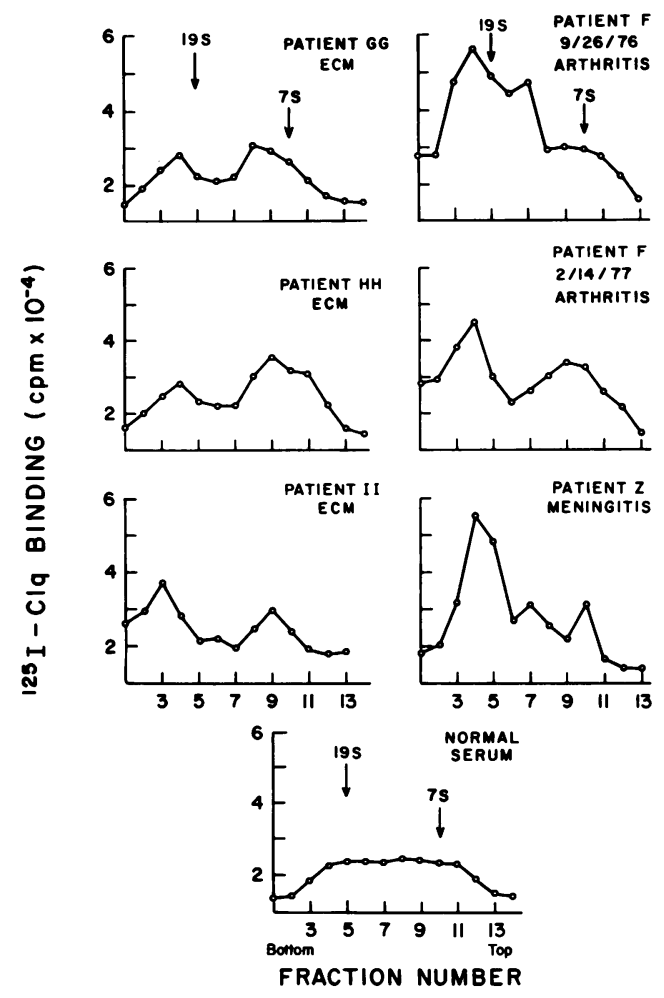

FIGURE $2{ }^{125} \mathrm{I}-\mathrm{Clq}$ binding is shown in individual $10-40 \%$ sucrose density gradient fractions of sera from patients with various manifestations of Lyme arthritis. The fractions were collected from the bottom of the gradient. The position of the $19 S$ and $7 \mathrm{~S}$ markers are indicated.

for reactivity in the $7 \mathrm{~S}$ region included larger complexes made less dense by a high lipid content, antibodies directed against $\mathrm{Clq}$, or other nonimmunoglobulin substances reacting with Clq.

It seemed possible that the $7 \mathrm{~S}$ and the $19 \mathrm{~S}$ material detected by ${ }^{125} \mathrm{I}-\mathrm{Cl}$ q binding might react differently in the other assays and thus account for the variability that we observed. Consequently, we also examined a group of fractionated sera with the Clq solid phase and the Raji cell assays (Fig. 3). The Clq solid phase assay detected reactivity in the region of the $19 \mathrm{~S}$ marker but little or no reactivity over background in the $7 \mathrm{~S}$ region. Thus, the $7 \mathrm{~S}$ reactivity in the ${ }^{125} \mathrm{I}-\mathrm{Cl} \mathrm{q}$ binding assay is unlikely to represent IgG-containing material. 7S reactivity in the Raji cell assay was present in sera not only of patients but of normal controls, and paralleled the serum concentration of monomeric IgG. Some patient sera also contained Raji cell reactivity in the $19 \mathrm{~S}$ region, but it was less prominent than $\mathrm{Clq}$ binding in either of the other two assays.

In summary, putative circulating immune complexes in Lyme arthritis sedimented near 195 and reacted equally well in the two Clq assays and less well in the Raji cell assay. A small amount of the reactivity in the ${ }^{125} \mathrm{I}-\mathrm{Clq}$ binding assay may be the result of a low density material that does not react in the $\mathrm{Clq}$ solid phase assay.

Tests for IgM and IgG rheumatoid factors. Tests for rheumatoid factors by latex agglutination were negative. Nevertheless, we considered the possibility that anti-immunoglobulins of the IgG class might be present and play a role in determining the pattern of Clq-reactive material in the density gradients. However, no evidence for IgG rheumatoid factor was found in 40 sera from patients with Lyme arthritis (Table II). In contrast, positive results were seen in 15 of 17 sera from patients with rheumatoid arthritis.

Clq reactivity of cryoglobulins. Some serum cryoglobulins contained ${ }^{125}$ I-Clq-reactive material (Table III). Blood from six patients with Lyme arthritis and cryoglobulinemia was allowed to clot at $37^{\circ} \mathrm{C}$, and the serum was removed. An aliquot (whole serum)

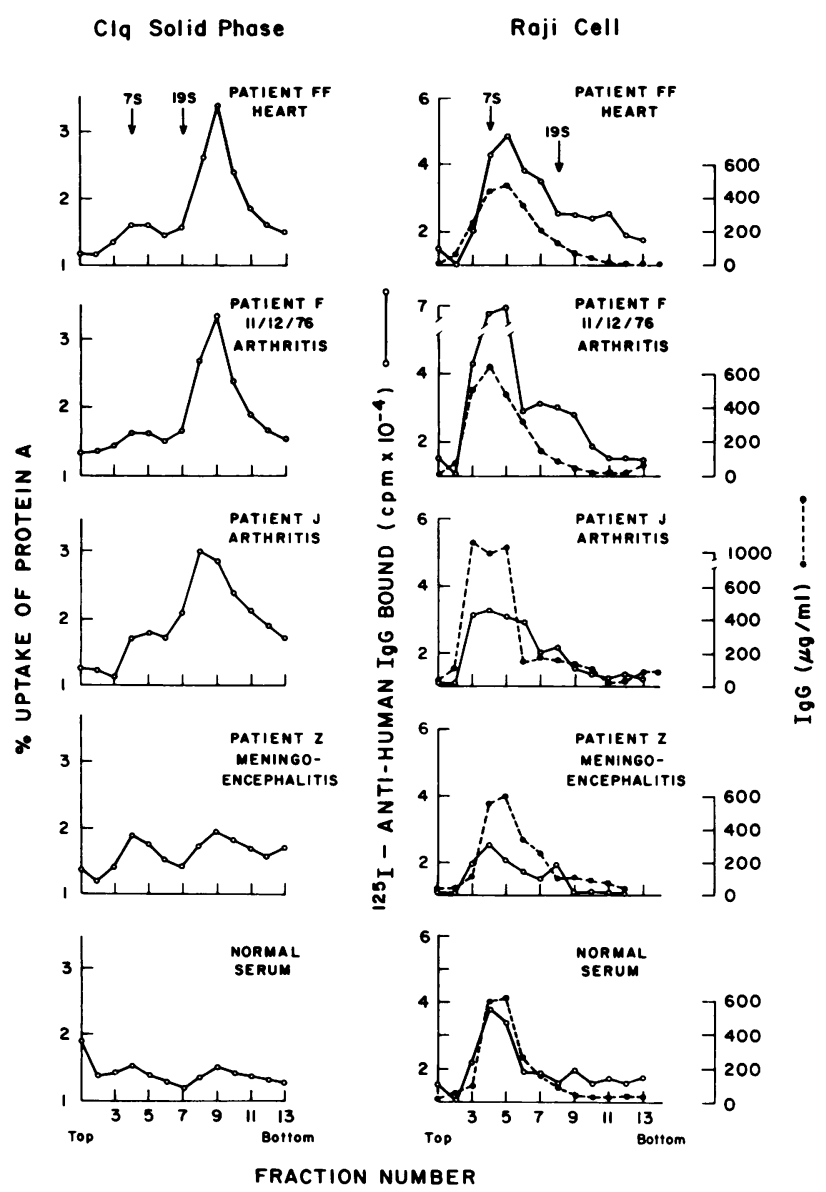

FIGURE 3 Reactivity of individual fractions from 10-37\% sucrose density gradients is compared in the Clq solid phase assay and the Raji cell assay. The fractions were collected from the top of the gradient (cf. Fig. 2). The predominant clinical feature of each patient and the position of the 19S and 7S markers are indicated. 
TABLE II

Test for IgG Rheumatoid Factor

\begin{tabular}{lcc}
\hline & Sera tested & Sera positive \\
\hline Lyme arthritis & 40 & 0 \\
Rheumatoid arthritis & 17 & 15 \\
Osteoarthritis & 7 & 0 \\
\hline
\end{tabular}

was tested immediately in the ${ }^{125} \mathrm{I}-\mathrm{Clq}$ binding assay. The remainder was stored at $4^{\circ} \mathrm{C}$ for $24 \mathrm{~h}$ and cryoprecipitable proteins were collected by centrifugation. Both the supernate (serum minus cryoglobulins), and the cryoprecipitable proteins redissolved in the starting volume of normal serum (control serum plus cryoglobulins), were tested. Removal of cryoprecipitable proteins caused a reduction in the ${ }^{125} \mathrm{I}-\mathrm{Clq}$ binding activity in five of the six sera. In three cases, from sera that had the most Clq binding activity to begin with, the cryoprecipitable proteins transferred $\mathrm{Clq}$ reactivity to the normal serum.

Patient studies. We investigated the relationship of circulating immune complexes to the course of Lyme arthritis by following a total of 58 patients during various phases of their illness, with the ${ }^{125} \mathrm{I}-\mathrm{Clq}$ binding assay (Table IV). 25 patients were tested within the first $3 \mathrm{wk}$ of the appearance of ECM. 20 had only ECM, whereas 5 had some additional complaints of joint discomfort, mainly arthralgias. Among this group, ${ }^{125}$ I-Clq-reactive material was found in $21(84 \%)$. After ECM disappeared, 9 of 10 patients with nervous system or heart involvement (5 with meningoencephalitis, 3 with cardiac conduction abnormalities, 1 with both, 1 with peripheral neuropathy) had ${ }^{125}$ I-Clq-reactive material in their blood. In contrast, among 17 patients with attacks of frank arthritis which occurred $4 \mathrm{wk}$ to 18 mo after the skin lesion, ${ }^{125} \mathrm{I}-\mathrm{Cl}$ q-reactive material

TABLE III

Clq Reactivity* of Cryoglobulins from Patients with Lyme Arthritis

\begin{tabular}{|c|c|c|c|}
\hline \multirow[b]{2}{*}{ Patient } & \multicolumn{2}{|c|}{ Patient serum } & \multirow{2}{*}{$\begin{array}{l}\text { Control serum } \mid \\
\text { plus redissolved } \\
\text { cryoglobulins }\end{array}$} \\
\hline & Whole & $\begin{array}{l}\text { Minus cryo- } \\
\text { globulins }\end{array}$ & \\
\hline 1 & 7.8 & 2.4 & 2.5 \\
\hline 2 & 7.7 & 6.7 & 3.2 \\
\hline 3 & 5.6 & 1.6 & 3.3 \\
\hline 4 & 2.5 & 1.4 & 0.4 \\
\hline 5 & 2.1 & 2.7 & 0.4 \\
\hline 6 & 2.0 & 1.5 & 0.6 \\
\hline
\end{tabular}

* ${ }^{125} \mathrm{I}-\mathrm{Clq}$ binding assay, expressed as SD above the mean of normal sera.

$\$$ Clq reactivity $0.4 \mathrm{SD}$ above the mean of other normal sera.
TABLE IV

Clq-Reactive Material during Different Phases of the Illness

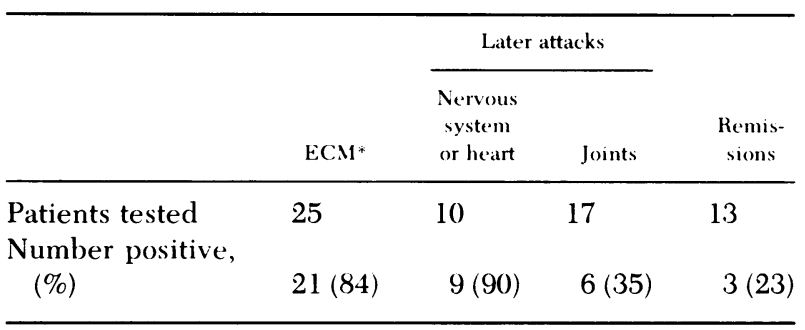

* Within $3 \mathrm{wk}$ of onset.

was found in only 6 (35\%). During remissions, positive reactions were obtained in only 3 of 13 patients (23\%).

The extent of $\mathrm{Clq}$ binding activity tended to parallel the clinical course of these patients. A representative case is illustrated in Fig. 4. This patient was a 58-yr-old man who developed ECM at the site of a tick bite $3 \mathrm{wk}$ before. At the time of his initial hospital visit in August 1977 he had faded ECM, atrial flutter with varying degrees of block, meningoencephalitis, Bell's palsy, and a peripheral sensory neuropathy. His serum initially produced a strongly positive reaction in the
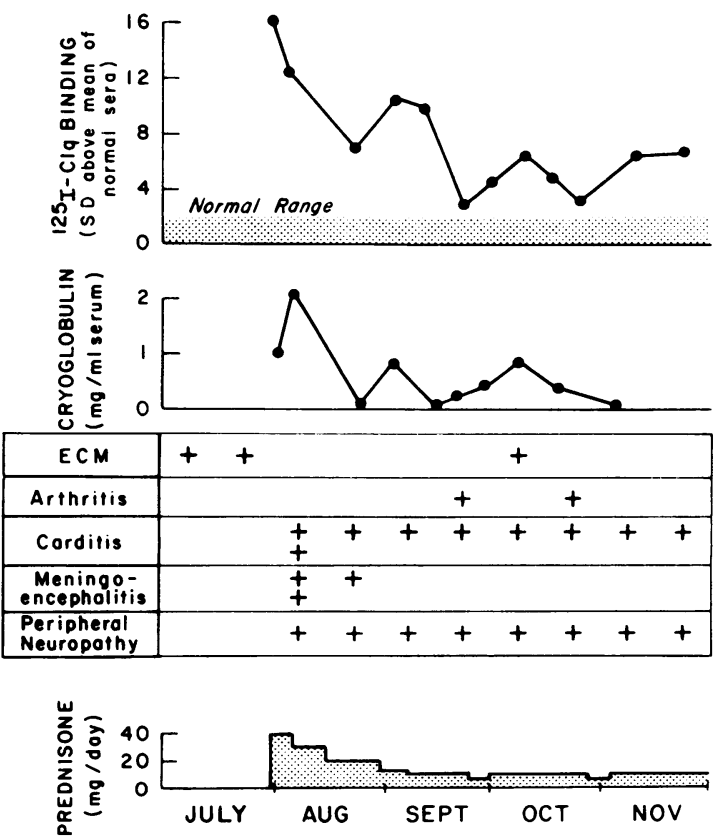

FIgUre 4 The clinical course is seen of a patient with Lyme arthritis. ECM and a variety of subsequent complications were associated with high levels of ${ }^{125} \mathrm{I}-\mathrm{Clq}$ binding activity. Although always abnormal, the level was highest near the onset of disease, and tended to decrease with clinical improvement (the latter reflected by the tapering of prednisone). A rebound occurred when ECM reappeared at its original site. Total cryoglobulins, not always positive, generally followed the level of binding activity. The shaded area shows the normal range of ${ }^{125} \mathrm{I}-\mathrm{Cl}$ q binding. 
${ }^{125} \mathrm{I}-\mathrm{Clq}$ binding assay and formed a heavy cryoprecipitate upon incubation at $4^{\circ} \mathrm{C}$ for $48 \mathrm{~h}$. Treatment with prednisone resulted in gradual clinical improvement associated with a parallel decrease in the serum ${ }^{125} \mathrm{I}-\mathrm{Cl}$ q binding activity and in cryoglobulins. In early October, ECM reappeared at its original site, followed by first degree heart block, frequent ventricular premature contractions, and pain in a knee and temporomandibular joint; ${ }^{125} \mathrm{I}-\mathrm{Clq}$ binding activity rose and cryoglobulins reappeared. As these problems resolved, ${ }^{125 I-C l q}$ binding activity and cryoglobulins returned to lower levels.

\section{DISCUSSION}

We have demonstrated that sera from patients with Lyme arthritis often react positively in three standard assays for immune complexes (Table I). The reactive material contained IgG, bound complement, was partially cryoprecipitable (Table III), and included a component that sedimented at 19S or greater (Figs. 2 and 3), a density consistent with immune complexes involving polyvalent antigens. Furthermore, the reactive material was disease related. It was much more prevalent in patients with active disease generally than in normal controls. Among patients, it was present primarily during periods of active disease (Tables I and IV), and it often rose and fell in parallel with clinical features of the illness (Fig. 4). For the most part, it was consistently either present or absent in serial samples from sick individuals (Table I, Fig. 4). These findings indicate that reliable measurements of a disease-associated substance-most likely immune complexes-were being made.

Many of the clinical and laboratory features of Lyme arthritis are compatible with a pathogenetic role for immune complexes. For example, short attacks of arthritis, peripheral neuropathies, cardiac conduction abnormalities, and involvement of the central nervous system are also features of human serum sickness (18). Moreover, certain patients with Lyme arthritis have serum cryoimmunoglobulins that contain Clq-reactive material (Table III); in those with ECM, the presence of such cryoproteins indicates an increased likelihood that subsequent attacks of arthritis will occur (3). The fact that serum levels of complement are usually normal or elevated (Fig. 1) may simply indicate that acceleration of complement production during active phases of disease is masking complement consumption. In rheumatoid arthritis, complement levels are usually normal, even when the activated component $\mathrm{C} 3 \mathrm{~b}$ is elevated in parallel with ${ }^{125} \mathrm{I}-\mathrm{C} 1 \mathrm{q}$ binding activity (19).

Each of the assays used in this study is dependent upon the ability of immune complexes to fix complement. Nevertheless, considerable differences may exist among the assays in the kind of complexes that are detected best, and in the factors that cause interference. The ${ }^{125} \mathrm{I}-\mathrm{Clq}$ binding assay can theoretically detect all immune complexes that bind $\mathrm{Clq}$, including those composed of IgM. This advantage is offset to a certain extent by the nonspecific reactivity of $\mathrm{Clq}$ with such substances as C-reactive protein, DNA, and endotoxin (20-22). In contrast, the Clq solid phase assay is theoretically specific for immune complexes containing immunoglobulin that reacts with both $\mathrm{Clq}$ and staphylococcal protein A-mainly $I G_{1}$, and $I_{g G}$ (23). Although this assay might fail to detect complexes composed of IgM, IgA, or $\operatorname{IgG}_{3}$, it avoids the possible influence of interfering substances. The Raji cell assay is also subject to a variety of interferences. It detects preferentially the larger complexes formed near antigen-antibody equivalence (9). Monomeric IgG also binds to these cells, as shown in Fig. 3. In addition, warm-reactive anti-lymphocyte antibodies might react with the (lymphocytic) Raji cell. Finally, C3b and C3d free in serum can displace immune complexes from the surface of Raji cells, and high levels of these components might cause false-negative reactions (24).

In the present work there was a remarkable correlation between the two Clq assays $(P<0.001)$. They each detected reactive material in about $45 \%$ of the sera from patients with active disease, and positive and negative results usually agreed (Table I). It is possible that this figure actually underestimates the true incidence of cirulating immune complexes. The sera that we studied had been collected at $25^{\circ} \mathrm{C}$, a temperature at which some cryoprecipitable immune complexes become insoluble (25). Thus, although the period of serum collection is short $(\cong l \mathrm{~h})$ and the temperature relatively high (compared to $4^{\circ} \mathrm{C}$, as in Table III), some Clq-reactive material may have been lost.

In contrast to the two Clq assays, the Raji cell assay was positive in only 10 sera $(23 \%)$. Among these, one reacted strongly and three less so when the other assays were negative. Although the Raji cell and the Clq solid phase assays are about equally sensitive for detecting aggregated IgG (23), we have identified similar discrepancies between the two in patients with disseminated gonococcemia (12) and with glomerulonephritis (23). These discrepancies may reflect differences in conformation and (or) size among immune complexes, that favor reactivity in one or another system.

The gradient studies demonstrated that reactive substances of two different densities were present in sera from patients with Lyme arthritis (Figs. 2 and 3). The higher density material sedimenting at approximately $19 \mathrm{~S}$ is compatible with the circulating immune complexes found in a number of other diseases, including rheumatoid arthritis (6) and cyto- 
megalovirus infection (26). Although precise identification of this material will require its isolation, dissociation, and specific reassembly, the fact that it is of high molecular weight, contains IgG, and reacts with $\mathrm{Clq}$ suggests that it represents antigen-antibody complexes. Immune complexes of this size are likely to initiate tissue injury (27), and it may be important that the largest amounts of this material were found in patients with severe clinical manifestations. The high density material was detected best in the assays based on Clq binding; thus, it is not surprising that sera from patients with active disease were more frequently positive in the ${ }^{125} \mathrm{I}-\mathrm{Clq}$ binding and the $\mathrm{Clq}$ solid phase assays than in the Raji cell assay.

The lower molecular weight material that reacted mainly in the ${ }^{125} \mathrm{I}-\mathrm{Clq}$ binding assay may be similar to Clq-reactive, low molecular weight substances found in some patients with systemic lupus erythematosus (28). Its density and its failure to be detected in the Clq solid phase assay are incompatible with complement fixing immune complexes. Nevertheless, it was not found in sera from normal donors and may be a disease-related substance. Its identification is therefore of interest, and further work is indicated on its specificity and relationship to disease activity.

\section{ACKNOWLEDGMENTS}

We wish to acknowledge and thank Joan Carboni and Evelyn Heapy for excellent technical assistance, and Elizabeth L. Tartagni for preparation of the manuscript.

This work was supported in part by grants from the U. S. Public Health Service (AM-20583, RR-00125, AM-10493, AM-07107, AI-11785, AMA-1-13824, AM-13690), the Arthritis Foundation and its Connecticut Chapter, the World Health Organization, and the Kroc Foundation of Santa Ynez, Calif.

\section{REFERENCES}

1. Steere, A. C., S. E. Malawista, D. R. Snydman, R. E. Shope, W. A. Andiman, M. R. Ross, and F. M. Steele. 1977. Lyme arthritis: an epidemic of oligoarticulr arthritis in children and adults in three Connecticut communities. Arthritis Rheum. 20: 7-17.

2. Steere, A. C., S. E. Malawista, J. A. Hardin, S. Ruddy, P. W. Askenase, and W. A. Andiman. 1977. Erythema chronicum migrans and Lyme arthritis: the enlarging clinical spectrum. Ann. Intern. Med. 86: 685-698.

3. Steere, A. C., T. F. Broderick, and S. E. Malawista. 1978. Erythema chronicum migrans and Lyme arthritis: epidemiologic evidence for a tick vector. Am. J. Epidemiol. 108: $312-321$.

4. Wallis, R. C., S. E. Brown, K. O. Kloter, and A. J. Main, Jr. 1978. Erythema chronicum migrans and Lyme arthritis: field study of ticks. Am. J. Epidemiol. 108: 322-327.

5. Steere, A. C., J. A. Hardin, and S. E. Malawista. 1977. Erythema chronicum migrans and Lyme arthritis: cryoimmunoglobulins and clinical activity of skin and joints. Science (Wash. D. C.). 196: 1121-1122.

6. Zubler, R. H., U. Nydegger, L. H. Perrin, K. Fehr, J. McCormick, P. H. Lambert, and P. A. Miescher. 1976.
Circulating and intra-articular immune complexes in patients with rheumatoid arthritis. Correlation of ${ }^{125} \mathrm{I}-\mathrm{Cl} \mathrm{q}$ binding activity with clinical and biological features of the disease. J. Clin. Invest. 57: 1308-1319.

7. Farrel, C., H. Sogaard, and S. E. Svehag. 1975. Detection of IgG aggregates of immune complexes using solidphase Clq and protein A rich Staphylococcus aureus as an indicator system. Scand. J. Immunol. 4: 673-680.

8. Hay, F. C., L. J. Nineham, and I. M. Roitt. 1976. Routine assay for the detection of immune complexes of known immunoglobulin class using solid phase Clq. Clin. Exp. Immunol. 24: 396-400.

9. Theofilopoulos, A. N., C. B. Wilson, and F. J. Dixon. 1976. The Raji cell radioimmune assay for detecting immune complexes in human sera. J. Clin. Invest. 57: 169-182.

10. Yonemasu, K., and R. M. Stroud. 1971. Rapid purification method for preparation of monospecific antisera and for biochemical studies. J. Immunol. 106: 304-313.

11. Heusser, C., M. Boesman, J. H. Nordin, and H. Isliker. 1973. Effect of chemical and enzymatic radioiodination on in vitro human $\mathrm{Clq}$ activities. J. Immunol. 110: 820-828.

12. Walker, L. C., T. D. Ahlin, K. S. K. Tung, and R. C. Williams, Jr. 1978. Circulating immune complexes in disseminated gonorrheal infection. Ann. Intern. Med. 89: 28-33.

13. Hunter, W. M., and F. C. Greenwood. 1962. Preparation of iodine-131 labelled human growth hormone of high specific activity. Nature (Lond.). 194: 495-496.

14. Hay, F. C., L. J. Nineham, and I. M. Roitt. 1975. Routine assay for detection of IgG and IgM antiglobulins in seronegative and seropositive rheumatoid arthritis. $\mathrm{Br}$. Med. J. 3: 203-204.

15. Singer, J. M., and C. M. Plotz. 1956. The latex fixation test. I. Application to the serologic diagnosis of rheumatoid arthritis. Am. J. Med. 21: 888-892.

16. Kent, J. F., and E. H. Fife. 1963. Precise standardization of reagents for complement fixation. Am. J. Trop. Med. Hyg. 12: 103-116.

17. Hyslop, Jr., N. E., R. R. Dourmashkin, N. M. Green, and R. R. Porter. 1970. The fixation of complement and the activated first component $(\mathrm{Cl})$ of complement by complexes formed between antibody and divalent hapten. J. Exp. Med. 131: 783-802.

18. von Pirquet, C. F., and B. Schick. 1905. Die Serum Krankheit. Deuticke, Leipzig. English translation by B. Schick. Serum Sickness. 1951. The Williams \& Wilkins Co., Baltimore.

19. Nydegger, U. E., R. H. Zubler, R. Gabay, G. Joliat, Ch. Karagevrekis, P. H. Lambert, and P. A. Miescher. 1977. Circulating complement breakdown products in patients with rheumatoid arthritis. J. Clin. Invest. 59: 862-868.

20. Claus, D. R., J. Siegel, K. Petras, A. P. Osmand, and H. Gewurz. 1977. Interactions of C-reactive protein with the first component of human complement. J. Immunol. 119: $187-192$.

21. Agnello, V., R. I. Carr, D. Koffler, and H. G. Kunkel. 1969. Gel diffusion reactions of $\mathrm{Clq}$ with aggregated $\gamma$-globulin, DNA and other anionic substances. Fed. Proc. 28: 2447. (Abstr.)

22. Loos, M., D. Bitter-Suermann, and M. Dierich. 1974. Interaction of the first (C1), the second (C2) and the fourth (C4) component of complement with different preparations of bacterial lipopolysaccharides and with lipid A. J. Immunol. 112: 935-940.

23. Tung, K. S. K., A. J. Woodroffe, T. D. Ahlin, R. C. Williams, Jr., and C. B. Wilson. 1978. Application of the 
solid phase Clq and Raji cell radioimmune assays for the detection of circulating immune complexes in glomerulonephritis. J. Clin. Invest. 62: 61-72.

24. Theofilopoulos, A. N., F. J. Dixon, and V. A. Bokisch. 1974. Binding of soluble immune complexes to human lymphoblastoid cells. I. Characterization of receptors for IgG Fc and complement and description of the binding mechanism. J. Exp. Med. 140: 877-894.

25. Meltzer, M., E. C. Franklin, K. Ellias, R. T. McCluskey, and N. Cooper. Cryoglobulinemia - a clinical and laboratory study. II. Cryoglobulins with rheumatoid factor activity. Am. J. Med. 40: 837-856.
26. Stagno, S., J. E. Volanakis, D. W. Reynolds, R. Stroud, and C. A. Alford. 1977. Immune complexes in congenital and natal cytomegalovirus infections of man. J. Clin. Invest. 60: $838-845$.

27. Cochrane, C. G., and D. J. Hawkins. 1968. Studies on circulating immune complexes. III. Factors governing the ability of circulating complexes to localize in blood vessels. J. Exp. Med. 127: 137-154.

28. Gabriel, Jr,, A., and V. Agnello. 1977. Detection of immune complexes. The use of radioimmunoassay with $\mathrm{Clq}$ and monoclonal rheumatoid factor. J. Clin. Invest. 59: 990-1001. 